\title{
Environmental Safety of Motor Transport Enterprises within the Urban Areas
}

\author{
Vitalina Lukianova', Oleksandr Trofymchuk², Yevheniia Anpilova ${ }^{2 *}$ \\ 1 Department of Ecology and Safety of Vital Functions, National Transport University, 01010, Omeljanovicha- \\ Pavlenka str. 1, Kyiv, Ukraine \\ 2 Department of Natural Resources, Institute of Telecommunications and Global Information Space of the \\ National Academy of Sciences of Ukraine, 03186, Chokolivsky Blvd, 13, Kyiv, Ukraine \\ * Corresponding author's e-mail: anpilova@ukr.net
}

\begin{abstract}
The water resources are the main component of technological processes occurring in industry; therefore, increasing the level of environmental safety, in particular, wastewater treatment without adverse impact on the environment and human health is relevant. The preliminary environmental analysis of the motor transport enterprise (MTE) activity has been carried out. It has been established that about twenty environmental aspects identified in the departments of technical inspection and repair and service have an adverse impact on the state of the environment. A substantial impact on the environment occurs when the sewage containing petroleum products, washing liquids, waste lubricants and contaminated by the products of tissue origin enters the soil and water objects and their resources. On the basis of the preliminary analysis, the authors have identified the environmental aspects of the company's activity and proposed an environmental policy as an essential element for the implementation of the environmental management system. The studies conducted with the aim of determining the motor transport enterprise sewage composition revealed an excessive content of polluting chemical substances, namely: suspended substances, phosphates, iron, fats, oil products and synthetic detergents. The expediency of using carbonaceous sorbents of vegetable origin, which were obtained from the waste wood industry for wastewater treatment of the enterprise, was investigated. It was revealed that the process of sorption purification improved the quality of wastewater of the motor transport enterprise to the standard values. The proposed recommendations for the implementation of the environmental management system will gradually reduce the impact of the company on the main components of the biosphere. Effective implementation of the environmental management system will help to increase the competitiveness of the enterprise and lead to an economic effect by saving raw materials, materials, energy resources, reducing the environmental fees and penalties.
\end{abstract}

Keywords: urban lands, environmental safety, oil products, sewage, purification methods, environmental management system.

\section{INTRODUCTION}

It is known that in 2017, the Government of Ukraine presented the National Report "Sustainable Development Goals: Ukraine". It covers the baseline for achieving seventeen Targets, taking into account the specifics of the national development. In order to achieve Goal No. 11 "Sustainable development of cities and communities" and Goal No. 6 "Ensuring the availability and rational use of water resources and sanitation for all", it is intended to reduce the adverse impact of pollutants, also on the environment of cities, through the use of innovative technologies; increase the efficiency of water use; reduce the volume of discharges of untreated sewage, first of all with the use of innovative technologies of water treatment at the state and local levels. In view of the above, the research aimed at preserving the water resources and introducing environmentally sound technologies and production should be considered as relevant. 
Most of the wastewater from industrial enterprises is characterized by a rather complex chemical composition, which depends on the type of production. The largest amount of wastewater is generated by enterprises belonging to the oil refining, metallurgical, automobile, chemical and pulp and paper industries [Leshchinska et al., 2012; Takeno et al., 2005].

Industrial, communal and municipal wastewater entering the water basins, constitute a serious threat to the living organisms, and contain harmful impurities able to change not only the qualitative composition of water, but also has an adverse impact on the circulation of substances in nature. It is known that oil hydrocarbons can increase their content by 10 times at each next level of the trophic chain [Avakyan and Shirokov, 1994]. For example, if oil hydrocarbons fall into plankton, then in the food chain to fish, then they accumulate 10 thousand times more than in the starting line, and 100 thousand times more than in water. These substances include, first and foremost, oil and the products of its processing, which are widely used in all areas of human life and are one of the largest pollutants of natural waters. Such contamination poses a serious threat to the health of people, animals and all living things in water and on the banks of water bodies [Khilchevsky et al., 2015].

In view of the above, it should be noted that the majority of motor transport enterprises of Ukraine (MTE) pollute the hydrosphere with the wastewater containing excessive quantities of oil products. This is due to the fact that MTEs do not sufficiently treat the sewage, which are formed and do not put the system of environmental management into effect.

The authors [Ogorodnikova, 2001; NelsonSmith, 1973; Ivanov et al., 2004; Bychenok and Trofymchuk, 2002] believe that the largest environmental hazard among sources of water bodies pollution are the oil spills as a result of tanker accidents (40\%), pumping oil products through main pipelines (27\%), and $16 \%$ are losses when storing oil products.

In any case, globally, the pollution of the hydrosphere is an issue of environmental safety [Sokur et al., 2011]. The sources of water basins pollution by oil and its derivatives are diverse. The wastewater from many industrial enterprises contains diesel fuel, lubricants, fuel and other petroleum products [Alturkmani Abdulrzzak, 2013]. The environmental pollution control requires significant funding; however, while analyzing the national and international scientific and practical research [Takeno et al., 2005; Avakyan and Shirokov, 1994; Alturkmani Abdulrzzak, 2013], it can be observed that the costs of preventing the adverse impacts of pollution are much lower than the economic losses from the environmental pollution [Matveeva, 2001]. Bearing this in mind, among many environmental issues, one of the most important is to develop the methods for the MTE wastewater treatment [Satybaldiyeva et al., 2001; Tchobanoglous et al., 2003] and put the environmental management system into effect [Sokur et al., 2011; Matveeva, 2001].

MTE wastewater, depending on the production activity, is divided into: the wastewater from washing cars that are the part of circulating water supply system; precipitation containing the oil products and aluminum salts; oil wastewater after the floater. The wastewater generated as a result of the car wash and due to the surface runoff from the enterprises territories (is $80-85 \%$ of the total volume of MTE wastewater), in addition to the oil products, they are contaminated with a significant amount of suspended substances, which complicates the treatment process of these wastewaters. The concentration of suspended substances in the surface runoff ranges from tens and hundreds of milligrams per liter to tens of thousands. According to the content of oil products - from 1-2 mg / 1 to $70-120 \mathrm{mg} /$ liter. According to the rules for wastewater discharge into a sewage network, the content of suspended solids in them should not exceed $500 \mathrm{mg} / 1$, petroleum products $-20 \mathrm{mg} / 1$ [Bozhydarnik et al., 2011].

The treated wastewater from the car washing process form [Ludchenko, 2003] waste of the III class of hazard: emulsions and mixtures of oil products, a surface oil slick from petroleum dischargers, and sludge from oil extraction plants. The analysis shows that the main sources of wastewater pollution includes suspended substances and oil products. The oil products can be oxidized during the biological treatment of wastewater. High concentrations of oil products have a negative impact on the quality of active sludge and make the operation of urban wastewater treatment plants more complicated. In this respect, there are problems with the local treatment of the oil-containing wastewater prior to their discharge into the municipal sewage system. In practice, the mechanical, physicochemical, 
coagulation [Draginsky et al., 2005], extraction, biological and other methods of treatment [Govorova, 2003] are used, which in many cases are not sufficiently effective [Alekseev, 2007]. The effectiveness of wastewater treatment depends on the chosen method. One of the most promising methods is the sorption technology for their treatment [Sirotkina, 1997; Solodovnik, 2005; Ahmad et al., 2005; Petrushka et al., 2013; Kravchenko and Shvets, 2004].

The activities of MTS ensure the functioning of the transport system and should be aimed at achieving the goals of sustainable development. The provision of quality road transport services should include reducing environmental impact, reducing production costs and ensuring environmental safety. Therefore, one of the ways of improving the environmental safety of any MTE is to introduce an effective environmental management system (CEM), which will reduce the environmental impact.

The purpose of the work is to analyze the activities of the MTE departments, to determine the environmental aspects and environmental impact of the enterprise, and to establish the composition of wastewater to provide recommendations for improving of their quality through the use of sorption methods of treatment and introduction of environmental management system.

In order to achieve the goal, a number of tasks have been solved:

- to analyze the main issues of hydrosphere pollution by oil and petroleum products;

- to determine the composition of MTE sewage by an experiment;

- to investigate the sorption method of sewage containing oil products treatment;

- to identify the environmental aspects of the activity and develop the EMS environmental policy for the MTE under investigation.

\section{MATERIALS AND METHODS}

Among the traditional general scientific methods in the given work the following ones were used: analysis and synthesis (research of properties and factors of MTE wastewater impact); comparison and analogy; generalization and abstraction; physicochemical analysis (determination of the qualitative composition of MTE wastewater); methods of the environmentally oriented management (introduction of EMS at the MTE).
MTE No. 2 (Kyiv) was chosen as the basis for conducting studies. It is subordinated to the „Kyivpastrans” public utility Company. The main activity of the enterprise is the municipal passenger transportation. The territory of the enterprise is fenced, it has three exit road gates, and technical control point for checking the technical condition of cars. Maintenance and repair of the cars takes place at the posts of car repair shops. Maintenance and repair of rolling stock is carried out at the production sites of the current repair, diagnostics, bodywork, painting, washing and other departments.

The studies on the determination of the wastewater quality factors were carried out twice a week during 2 months in the environmental laboratory of the National Transport University. Investigations of the wastewater sorption treatment of the MTE were conducted under static conditions.

As sorbents for the treatment of MTE oil containing wastewater, the carbonaceous sorbents of plant origin were used. They were obtained from waste wood industry: sawdust of pine, birch, walnut in the mode of low temperature single stage carbonization in the range of temperatures 250 $450^{\circ} \mathrm{C}$ with a step of $50 \mathrm{C}$ and at duration from 3 to 15 minutes in 3 minute increments.

\section{RESULTS AND DISCUSSION}

In order to assess the effectiveness of MTE environmental management a preliminary environmental evaluation (PEE) has been carried out to determine the impact of the enterprise on the environment, and to determine the environmental aspects that are subject to control. About twenty aspects that have an adverse impact on the environment as a result of the activities of the departments of technical inspection and repair and service have been identified (Fig.1).

The most significant impact on the environment is due to the fuel consumption, as a result of the formation of waste lubricants and due to the wastewater containing oil products and washout liquids penetration into soil, water objects and their resources. Therefore, the main intentions of the company, which should be stated in the MTE environmental policy will be: a tendency to adhere to the standards established for the emissions of pollutants into the atmosphere, discharges in water objects, 


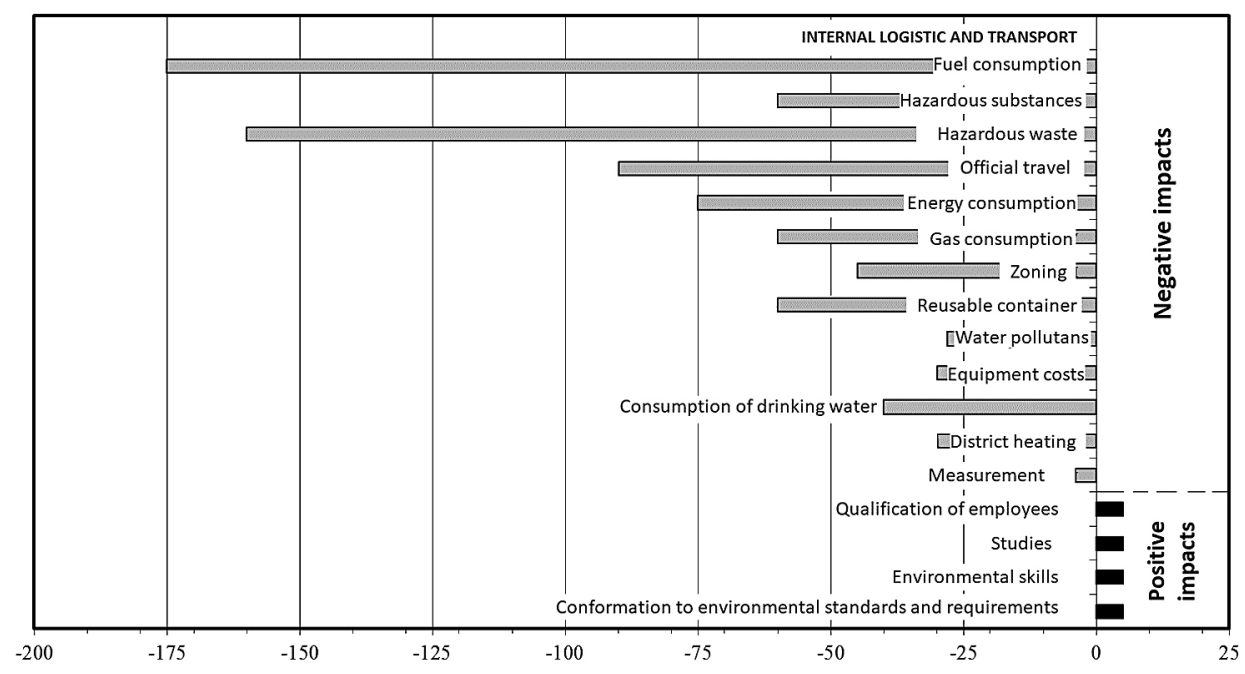

Figure 1. The importance of impact factors of the MTE activity on the environment

the formation and placement of waste; to ensure the fullest possible recycling and reuse of waste; to carry out production processes, guided by the priority of prevention and avoidance of environmental pollution; to plan the actions on the reduction of environmental risks, minimization of impact from possible emergency situations on the environment; to follow the priorities of energy and resource saving, rational use of natural resources, raw materials. On the basis of the above-mentioned document, an environmental program, indicating the goals and objectives for the gradual achievement of effective EMS should be developed.

It should be noted that there is no environmental response unit at the MTE, and the solving of the environmental tasks is assigned to the chief technologist, who primarily carries out his immediate responsibilities. Therefore, the environmental activities are reduced mainly to the fulfillment of the formal requirements of the current environmental legislation.

On the basis of certain environmental aspects on the impact of the enterprise on the environment, the authors of the article proposed monitoring the production activities, and assessing the environmental impact of environmental activities on the basis of EMS introduction in accordance with DSTU ISO 14001: 2015 standard.

On the basis of the data of the PEE, which revealed a high level of environmental impact of the wastewater that is generated as a result of the MTE departments activity, it was decided to perform a wastewater analysis for a number of chemical parameters (Table 1).
The obtained results (Table 1) demonstrate that for some factors the MTE wastewater exceeds the regulatory requirements for the wastewater discharge into municipal sewage system. The high content of phosphates and synthetic surface active agents (SAA) indicates the excessive use of synthetic detergents (SD) with a high SAA content, due to the intention to improve the quality of the washing up and significantly reduce the amount of the water used. The use of SD leads to the formation of stable emulsions with runoff dispersion (motor oil and gasoline). The formation of stable emulsions results in the unsuitability of the mechanical methods for cleaning up the washing stock for use in car washing.

In order to reduce the content of oil products, the authors have investigated sorption treatment of the MTE oil containing wastewater. The advantages of the sorption technology are the ability to deeply treat the wastewater of any concentration of oil products without the use of chemical reagents. Today, a number of oil-absorbing sorbents are known on the mineral, carbon and synthetic basis. Studies showed that the most effective treatment is achieved with the use of the carbon sorbents derived from the waste wood industry and agriculture with the method of low temperature single stage carbonization, which not only have high value of oil capacity, but are also characterized by environmental friendliness, and low cost [Takeno et al., 2005].

The use of the sorption methods is most rational. The efficacy of MTE wastewater treatment by carbonaceous sorbents based on vegetable waste, capable of purifying the MTE oil containing 
Table 1. Main qualitative indicators of MTE wastewater before and after the sorption treatment

\begin{tabular}{|l|c|c|c|}
\hline \multirow{2}{*}{\multicolumn{1}{|c|}{ Criteria }} & \multirow{2}{*}{$\begin{array}{c}\text { Sewage characteristic } \\
\text { value prior to discharge } \\
\text { into municipal sewerage }\end{array}$} & Output sewage & $\begin{array}{c}\text { Sewage after sorption } \\
\text { treatment }\end{array}$ \\
\cline { 3 - 4 } & - & oil & whisper oil \\
\hline Smell & - & light grey yellow & light grey \\
\hline Colour & $6.5-9.5$ & 8.5 & 7.2 \\
\hline $\mathrm{pH}(\mathrm{pH}$ unit) & - & muddy & slightly muddy \\
\hline Muddiness & 10000 & 520.0 & 325.0 \\
\hline Dry residues $\left(\mathrm{mg} / \mathrm{dm}^{3}\right)$ & 300.0 & 308.9 & 95.0 \\
\hline Suspended substances $\left(\mathrm{mg} / \mathrm{dm}^{3}\right)$ & 8.0 & 8.9 & 3.2 \\
\hline Phosphates $\left(\mathrm{mg} / \mathrm{dm}^{3}\right)$ & 20.0 & 11.9 & 5.4 \\
\hline Nitrogen ammonium $\left(\mathrm{mg} / \mathrm{dm}^{3}\right)$ & 500.0 & 253.7 & 30.3 \\
\hline Acid capacity $(\mathrm{COD})\left(\mathrm{mg} / \mathrm{dm}^{3}\right)$ & 240.0 & 50.8 & 20.4 \\
\hline Chloride $\left(\mathrm{mg} / \mathrm{dm}^{3}\right)$ & 380.0 & 75.8 & 1.3 \\
\hline Sulphates $\left(\mathrm{mg} / \mathrm{dm}^{3}\right)$ & 2.0 & 2.5 & 1.05 \\
\hline Iron $($ total $)\left(\mathrm{mg} / \mathrm{dm}^{3}\right)$ & 4.5 & 6.8 & 9.4 \\
\hline Oil products $\left(\mathrm{mg} / \mathrm{dm}^{3}\right)$ & 20.0 & 31.5 & 12.5 \\
\hline Anionic-Surfactants $\left(\mathrm{mg} / \mathrm{dm}^{3}\right)$ & 50.0 & 39.4 & \\
\hline Fats $\left(\mathrm{mg} / \mathrm{dm}^{3}\right)$ & & & \\
\hline
\end{tabular}

waters to an environmentally safe level is shown. As a result of the study, it was found that the process of sorption treatment reduced the content of the substances under investigation in the MTE wastewater, their concentration at the outlet from the MTE corresponds to the regulatory values.

\section{CONCLUSIONS}

In order to carry out efficient EMS and obtain an economic benefit, it is necessary to create an Environmental Service at the MTE, which will:

- make investment decisions, taking into account the environmental priorities and environmental impact;

- carry out the training of the personnel aimed at increasing the environmental consciousness of the employees of the Company, understanding of responsibility for the state of the environment;

- involve the personnel of the Company into activities aimed at improving the EMS in order to achieve the goals and objectives in the field of environmental protection;

- inform the employees of the enterprise, the public, and other interested parties about the Company's activities in the field of environmental protection;

- improve the environmental policy and the EMS program in order to increase the overall efficiency of the environmental activity of the MTE;

- seek recognition of the MTE by the public as a Company with a high environmental reputation and responsibility;

- participate in conducting the research on wastewater treatment and reduction or complete elimination of waste.

As a result of the preliminary environmental analysis of MTE No. 2 activities, the environmental aspects and the types of environmental impact of the Company were identified. It has been determined that the most needed adjustments to environmental aspects are related to the processes during the maintenance and repair of rolling stock. The elaborated version of the environmental policy on the basis of significant environmental aspects will focus on the priority issues that need to be addressed to reduce the negative impact on the environment during the work carried out in the departments of the enterprise.

The efficiency of the MTE wastewater treatment by carbonaceous sorbents on the basis of vegetable waste, capable of treating MTE oily wastewaters to an environmentally safe level was revealed.

Further research will be carried out in the direction of determining and calculating the total costs for the implementation of the environmental management system MTE No. 2. 


\section{REFERENCES}

1. Ahmad A., Sumathi S., Hameed B.H. 2005. Residual oil and suspended solid removal using natural adsorbents chitosan, bentonite and activated carbon: A comparative study, Chemical Engineering Journal, 108. 179-185.

2. Alekseev E.V. 2007. Fiziko-himicheskaja ochistka stochnyh vod (Physico-chemical treatment of sewage), Publishing of the DIA (in Russian).

3. Alturkmani Abdulrzzak 2013. Industrial wastewater.. https://www.researchgate.net/ publication/249656190_industrial_wastewater.

4. Avakyan A.B., Shirokov V.M. 1994. Racional'noe ispol'zovanie vodnyh resursov (Rational use of water resources) Yekaterinburg: the edition ,Victor” (in Russian).

5. Bozhydarnik V.V., Kartava O.V., Kartavi A.G. 2011. Ochyshhennja stichnyh vod avtotransportnyh pidpryjemstv iz zastosuvannjam energozberigajuchyh kompaktnyh ochysnyh sporud (EKOS) (Wastewater treatment of motor transport enterprises with the use of energy-saving compact treatment plants (ECOS), Modern problems of production and repair in industry and transport. Materials of the 11th International Scientific and Technical Seminar (in Ukrainian).

6. Bychenok, M.M., Trofymchuk O.M. 2002. Problems of natural-technogenic safety in Ukraine (Problemy pryrodno-tekhnohennoi bezpeky v Ukraini), Kyiv: UIERS (in Ukrainian).

7. Draginsky V.L., Alekseev L.P., Hetmantsev S.V. 2005. Koaguljacija v tehnologii ochistki prirodnyh vod (Coagulation in natural water purification technology), Scientific publication (in Russian).

8. Govorova Zh.M. 2003. Vybor i optimizacija vodoochistnyh tehnologij (Selection and optimization of water purification technologies), Vologodsk State Technical University (in Russian).

9. Ivanov S.V., Boichenko S.V., Shvets O.V. 2004. Doslidzhennja adsorbcii' vuglevodnevyh sumishej (Investigation of adsorption of hydrocarbon mixtures) Reports of the National Academy of Sciences of Ukraine, 2, 152-156 (in Ukrainian).

10. Khilchevsky V.K., Zaboritskaya M.R., Kravchinsky R.L., Chunarev O.V. 2015. Osnovni zasady upravlinnja jakistju vodnyh resursiv ta jihnja ohorona: navch. posibnyk (Basic principles of water quality management and its protection: training. Manual) „Kyiv University” CPC (in Ukrainian).

11. Kravchenko O.V., Shvets D.I. 2004. Doslidzhennja sorbciji naftoproduktiv iz vodnoji poverhni vuglecevymy materialamy na osnovi roslynnoji syrovyny (Investigation of the sorption of petroleum products from the water surface by carbon materials on the basis of plant raw materials). Chemistry, physics and surface technology: Coll. sciences Ave, 10, 161-165 (in Ukrainian).

12. Leshchinska A.L., Zelen'ko Yu. V., Sandovsky M. 2012. Rozrobka resursozberigajuchyh tehnologij utylizaciji vidprac'ovanyh mastyl'no-oholodzhujuchyh ridyn (Development of resource-saving technologies for waste lubricant-cooling liquids utilization). Railway transport of Ukraine, 5, 29-31 (in Ukrainian).

13. Ludchenko O.A. 2003. Tehnichne obslugovuvannja i remont avtomobiliv (Maintenance and repair of cars), Znannja Pres (in Ukrainian).

14. Malyovy M.S., Petrushka I.M., Malik Yu.O., Petrushka K.I. 2013. Perspektyvnist' vykorystannja pryrodnyh sorbentiv dlja zabezpechennja ekologichnoji bezpeky vodnoresursnogo potencialu derzhavy (The prospect of using natural sorbents for ensuring environmental safety of the water resource potential of the state) Scientific Bulletin of NLTU of Ukraine. Collection of scientific and technical works, 68-75 (in Ukrainian).

15. Matveeva O. L. 2001. Ekologo-ekonomichna ocinka dijal'nosti pidpryjemstv aviapalyvozabezpechennja (Ecological-economic evaluation of the activities of the aviation fuel supply enterprises). Bulletin of the NAU, 3(10), 178-181 (in Ukrainian).

16. Nelson-Smith A. 1973. Zagrjaznenie morja neft'ju (Pollution of the sea by oil). Gidrometeoizdat (in Russian).

17. Ogorodnikova A.A. 2001. Sistema avtomatizirovannogo monitoringa zagrjaznenij morskoj sredy zaliva Petra Velikogo (The system of automated monitoring of pollution of the marine environment of the Gulf of Peter the Great) Materials of the regional scientific and practical conference „Improvement of the system of protection of marine waters and coastal zones from oil pollution”. Vladivostok: Dvgma, 80-83. (in Russian).

18. Satybaldiyeva D.K., Askarova A.I., Sharcheeva E.B., Askarova N.I. Ochistka stochnyh vod avtoremontnogo predprijatija (Cleaning the sewage of the car repair enterprise). http://arch.kyrlibnet.kg/uploads/Satybaldiyeva\%20D.K.,\%20Askarova\%20A.I.,\%20Sharsheeva\%20E.B.,\%20Askarova\%20N.I..pdf (in Russian).

19. Sirotkina EE, Ivanov VG, Glazkov O.V., Volkova G.I., Glazkova E.A. 1997. Primenenie novyh adsorbentov dlja kompleksnoj ochistki vody (Application of new adsorbents for complex water treatment), Chemistry in the interests of sustainable development, 5(4), 429-437 (in Russian).

20. Sokur M.I, Shmandiy V.M., Gavrilov P.S., Latyshev K.O., Kharlamova O.V. 2011. Ekonomichni aspekty ekologichnoji bezpeky (monografija) (Economic aspects of environmental safety (monograph). Kremenchuk: P.P. Shcherbatykh. (in Ukrainian).

21. Solodovnik T.V. 2005. Application of chitincontaining sorbents for theatment of water solution, Abstracts of NATO advanced research workshop: Combined and hybrid adsorbents: fundamentals and applicationsll, Kiev, Ukraine.

22. Takeno K., Yamaoka Y., Sasaki K. 2005. Treatment of Oil-containing Sewage Wastewater Using Immobilized Photosynthetic Bacteria. Journal of Microbiology and Biotechnology, 21(8-9), 1385-1391.

23. Tchobanoglous G., Burton F.L. and Stensel H.D. 2003. Wastewater Engineering (Treatment Disposal Reuse), Metcalf \& Eddy, Inc. ( ${ }^{\text {th }}$ ed.) McGraw-Hill Book Company. 